\title{
Hardness and wear resistance improvement of Ferro Casting Ductile for permanent mold
}

\author{
Agus Yulianto $^{1,2}$, Rudy Soenoko ${ }^{3}$, Wahyono Suprapto ${ }^{4}$, As'ad Sonief $^{5}$, Agung Setyo Darmawan ${ }^{6}$ \\ ${ }^{1}$ Department of Mechanical Engineering, Faculty of Engineering, Universitas Muhammadiyah Surakarta, \\ Indonesia, ay160@ums.ac.id \\ ${ }^{2}$ Department of Mechanical Engineering, Faculty of Engineering, Brawijaya University, Indonesia, \\ ay160@ums.ac.id \\ ${ }^{3}$ Department of Mechanical Engineering, Faculty of Engineering, Brawijaya University, Indonesia, \\ rudysoen@ub.ac.id \\ ${ }^{4}$ Department of Mechanical Engineering, Faculty of Engineering, Brawijaya University, Indonesia, \\ wahyos@ub.ac.id \\ ${ }^{5}$ Department of Mechanical Engineering, Faculty of Engineering, Brawijaya University, Indonesia, \\ Sonief@ub.ac.id \\ ${ }^{6}$ Department of Mechanical Engineering, Faculty of Engineering, Universitas Muhammadiyah Surakarta, \\ Indonesia, Agung.Darmawan@ums.ac.id
}

\begin{abstract}
The purpose of this work is to investigate effect of the flame hardening process on hardness and wear rate of ferro casting ductile for permanent mold. The process of flame hardening was carried out by heating the edge of the specimen with an oxy-acetylene flame to temperature of $900{ }^{\circ} \mathrm{C}$, and then followed by quenching process on the edge that was burned. The Vickers hardness testing was carried out on specimens with flame hardening and without flame hardening. The hardness was conducted at five points, namely at a distance of $1 \mathrm{~mm}, 2 \mathrm{~mm}, 3 \mathrm{~mm}, 25 \mathrm{~mm}$ and $54 \mathrm{~mm}$ from the edge. Wear test was conducted by using Abrasive Wear Test. From the results of hardness and wear test, the hardness of specimens without flame hardening at a distance of $1 \mathrm{~mm}, 2 \mathrm{~mm}, 3 \mathrm{~mm}$, $25 \mathrm{~mm}$ and $54 \mathrm{~mm}$ from the edge were $137.3 \mathrm{HVN}, 141.1$ HVN, 137.3 HVN, 130.1 HVN and 137.3 HVN, respectively. In the wear test, the weight loss for specimens without flame hardening process was $184.3 \mathrm{mg}$. While for the specimens that were processed by flame hardening, the hardness obtained at a distance of $1 \mathrm{~mm}, 2 \mathrm{~mm}, 3 \mathrm{~mm}, 25 \mathrm{~mm}$ and 54 $\mathrm{mm}$ from the edge were $328.8 \mathrm{HVN}, 249.7 \mathrm{HVN}, 117.4 \mathrm{HVN}$, 120.4 HVN and 117.4 HVN, respectively. The weight loss specimen with a flame hardening process was $136.3 \mathrm{mg}$. There were increasing hardness and wear resistance after flame hardening processes.
\end{abstract}

Key words: Ferro Casting Ductile, Flame Hardening, Hardness, Permanent Mold, Wear

\section{INTRODUCTION}

A machine has many components that work on movement with friction. In relative motion with compressive stress, friction always occurs in the contact plane. Then the abrasion will occur and reduce the accuracy of the components which subsequently develop continues to become more severe until the engine component loses its function and fails. To avoid this, it is needed a material that has suitable hardness and wear resistance properties on the surface. Ferro casting ductile is a type of cast iron that is often used. Because this cast iron has good ductility, corrosion resistance, wear resistance and heat resistance [1]-[3].

Cast iron widely used as a material for making cast objects, such as household furniture [4], pipings [5]-[7], wire rope drives [8] and automotive component [9]-[11]. Cast iron phases are graphite and matrix (except white cast iron). Based on the shape of graphite, cast iron is divided into: white cast iron, gray cast iron, nodular cast iron and malleable cast iron. The properties of cast iron are determined by its basic structure, the shape of graphite [12] and other elements contained therein [13], [14]. The mechanic and physic properties are playing important role in design processes [15]-[17]

Ferro casting ductile has matrix phase similar to steel phase [18]. Therefore this cast iron micro structure can be transformed into a martensitic matrix with higher strength and hardness, by conducting surface hardening. Surface hardening is divided into flame/induction hardening [19] and thermo chemical hardening [20], [21]. Surface hardening 
aims not only to increase surface hardness, but also to increase wear resistance, fatigue resistance and corrosion resistance. Overall, the material will not experience a significant decrease in ductility and toughness

Surface treatment by flame hardening is a process of heating by high temperature flame on the surface of the material which is followed immediately by cooling which results in the transformation of the non equilibrium phase. Hardening occurs on the surface of material because of austenite transformation to martensite in steel, while the substrate property of the inner material does not change. [22].

Effect of surface temperature and cooling rate on residual stress and hardness by the flame hardening process in $12 \mathrm{Cr}$ steel was investigated by Lee et al. [23]. The results showed that increasing cooling rate increased surface hardness and the depth of hardening.

In this work, ferro casting ductile will be used as a material for permanent mold. Mechanical properties of the ferro casting ductile can be increased by heat treatment. One of the heat treatment processes is flame hardening. Therefore, this work aims to investigate effect of flame hardening process on physical and mechanical properties of nodular cast iron by analyzing hardness and wear rate.

\section{MATERIALS AND METHODS}

The material tested in this research was ferro casting ductile type 45 which was cast processed by using induction furnace. The size of the specimen is $25 \mathrm{~mm}$ in diameter and $55 \mathrm{~mm}$ in length. The composition of the ferro casting ductile can be seen in Table 1.

Table 1. The composition test result of ferro casting ductile

\begin{tabular}{cc}
\hline Element & $\begin{array}{c}\text { Composition } \\
(\boldsymbol{\%})\end{array}$ \\
\hline $\mathrm{Fe}$ & 89.80 \\
$\mathrm{Si}$ & 2.770 \\
$\mathrm{~V}$ & $<0.001$ \\
$\mathrm{~S}$ & 0.018 \\
$\mathrm{Mg}$ & $>0.038$ \\
$\mathrm{~W}$ & $<0.003$ \\
$\mathrm{C}$ & $>4.584$ \\
$\mathrm{Ni}$ & 0.025 \\
$\mathrm{Cr}$ & 0.067 \\
$\mathrm{Ti}$ & 0.010 \\
$\mathrm{Mn}$ & 0.615 \\
$\mathrm{Mo}$ & 0.018 \\
$\mathrm{Nb}$ & $<0.004$ \\
$\mathrm{P}$ & 0.022 \\
$\mathrm{Cu}$ & 0.014 \\
$\mathrm{Al}$ & 0.024 \\
\hline
\end{tabular}

Then two specimens were made for microstructure and hardness test specimens, one for those for the specimen without flame hardening process and one was processed by the flame hardening. After that, six wear test specimens were prepared. Three specimens for wear test without flame hardening process and three specimens for wear test using flame hardening process.

In this study, heat treatment was conducted by using the flame hardening process. This process is carried out by heating the test specimen surfaces to $900{ }^{\circ} \mathrm{C}$ with an oxy-acetylene flame. Then proceed by rapidly cooling the heated part by quenching the part in water. The flame hardening process was carried out on three wear test specimens and one microstructure and hardness test sample.

The Vickers hardness test is conducted with $40 \mathrm{kgf}$ indenter force for 15 seconds. This test is performed based on ASTM standard E92.

The wear rate testing of the test specimen is carried out using an Abrasive Wear Test. The test was base on ASTM G99 standard. The data taken is the difference in weight of the wear test specimen before being tested for wear and after the wear test. This test is carried out 3 times for each test specimen.

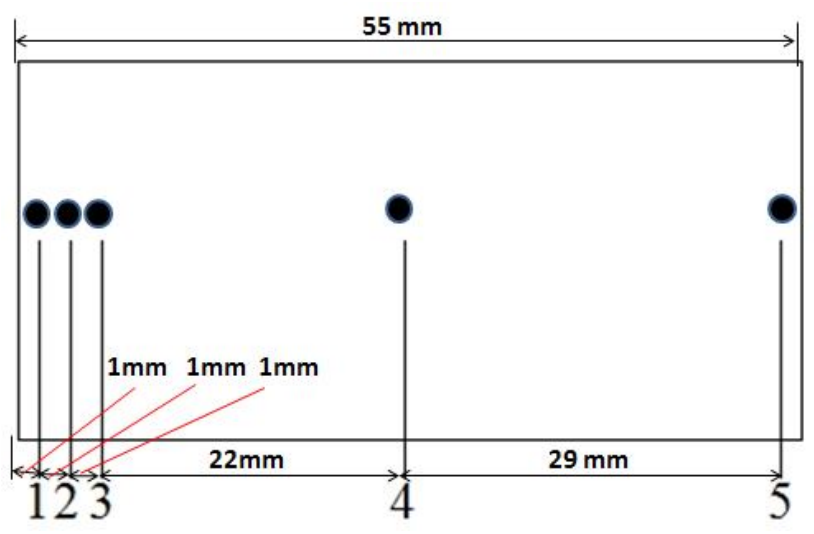

Figure 1: The location of Vickers hardness testing

\section{RESULTS AND DISCUSSIONS}

Microstructure testing was conducted by optical microscope, while picture was taken by photo microscopic system in the middle and both edges of the test specimen. Figure 2 shows the same phase in cast iron without flame hardening process. The phase is black spheroid graphite with bright colored ferrite surrounding it. The matrix of this cast iron is pearlite. However, it appears that the size of the graphite at the edges is slightly smaller than the middle. 


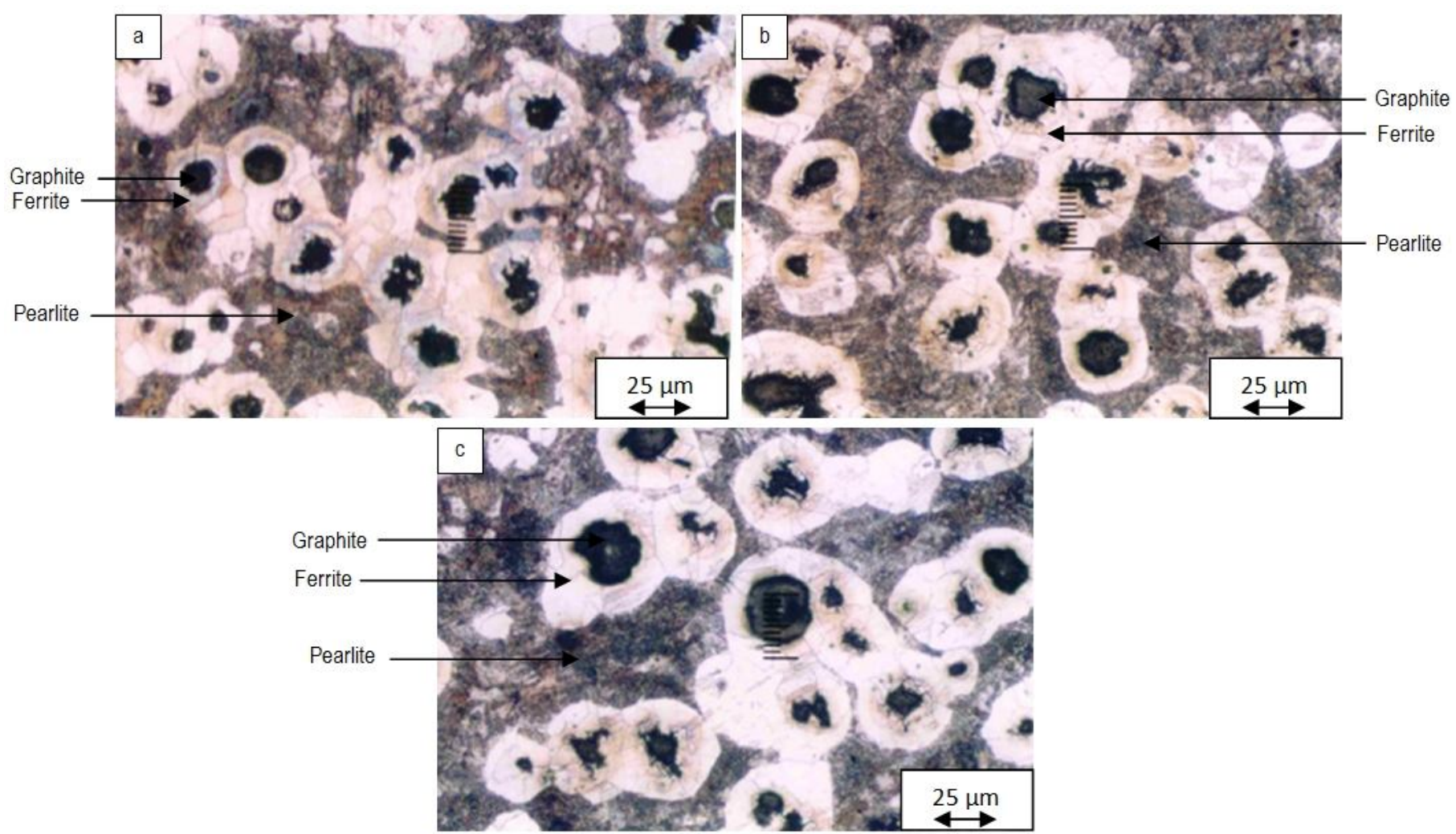

Figure 2:. The microstructure of raw material at (a) edge (b) middle (c) another edge

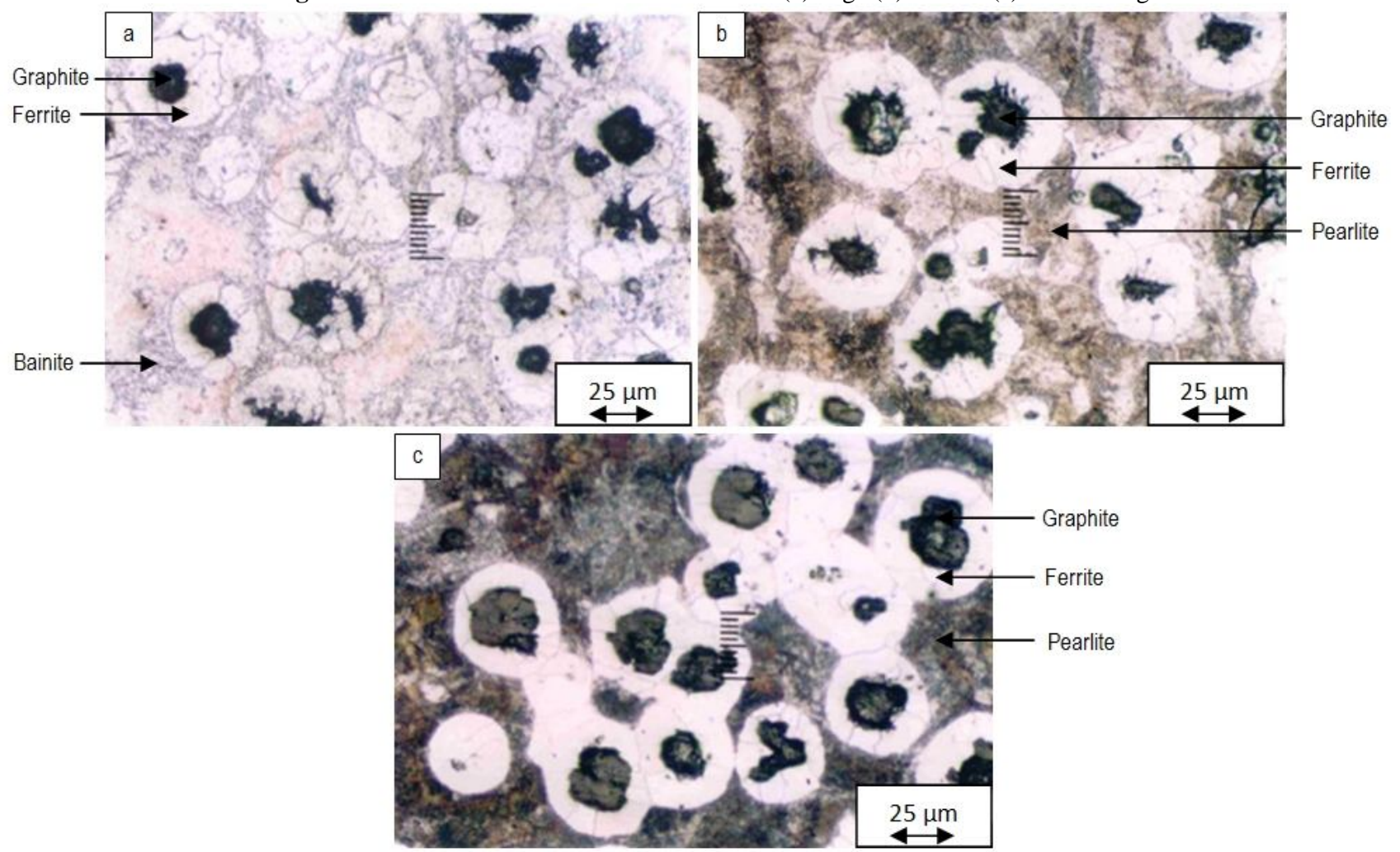

Figure 3: The microstructure of flame hardened ferro casting ductile at (a) flame hardened edge (b) middle (c) non flame hardened edge

In flame hardened specimens. The pearlite phase on the heated edge is transformed into austenite and in the quenching process the austenite is transformed into bainite. So as shown in Figure 3, bainite is formed at the edge of specimen which is flame hardened. While in the middle and other edges, the phase formed is spheroid graphite surrounded by ferrite and pearlite matrix. 
Vickers hardness tester was carried out with a loading of 40 $\mathrm{kg}$. Tests performed as much as 5 times each hardness test specimen whether processed flame hardening at the end or not. The test is carried out at a point $1 \mathrm{~mm}, 2 \mathrm{~mm}, 3 \mathrm{~mm}, 25$ $\mathrm{mm}$ and $54 \mathrm{~mm}$ from the flame hardened edge (see again Figure 2). The hardness test for specimen without flame hardening process has the same location with the flame hardened specimen. The hardness carried out at five different points is found that the specimens before processing flame hardening have the same hardness. However hardness at the edge of specimen slightly increases because of decreasing size and amounts of graphite. While, the specimens processed in flame hardening obtained varying hardness values. The flame hardened edge has the highest hardness of 328.8 VHN. The hardness test results can be seen in Figure 4. The bainite phase and reduction in the amount of graphite caused increasing hardness at the edge of the specimen.

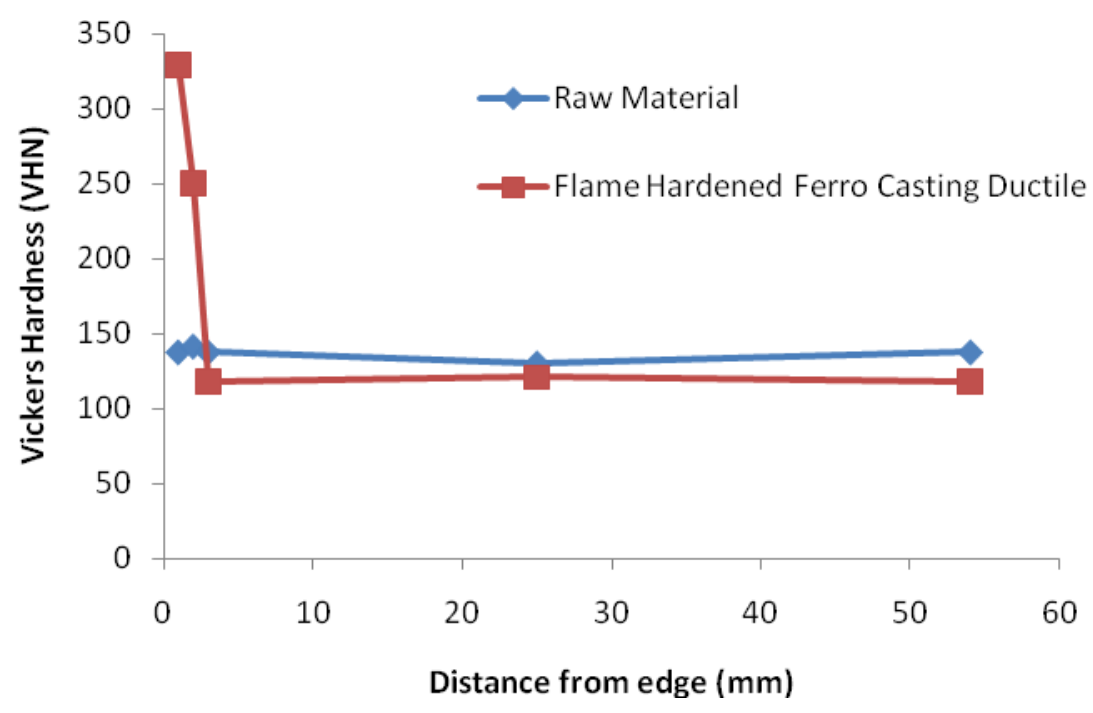

Figure 4: Hardenability of ferro casting ductile due to flame hardening process.

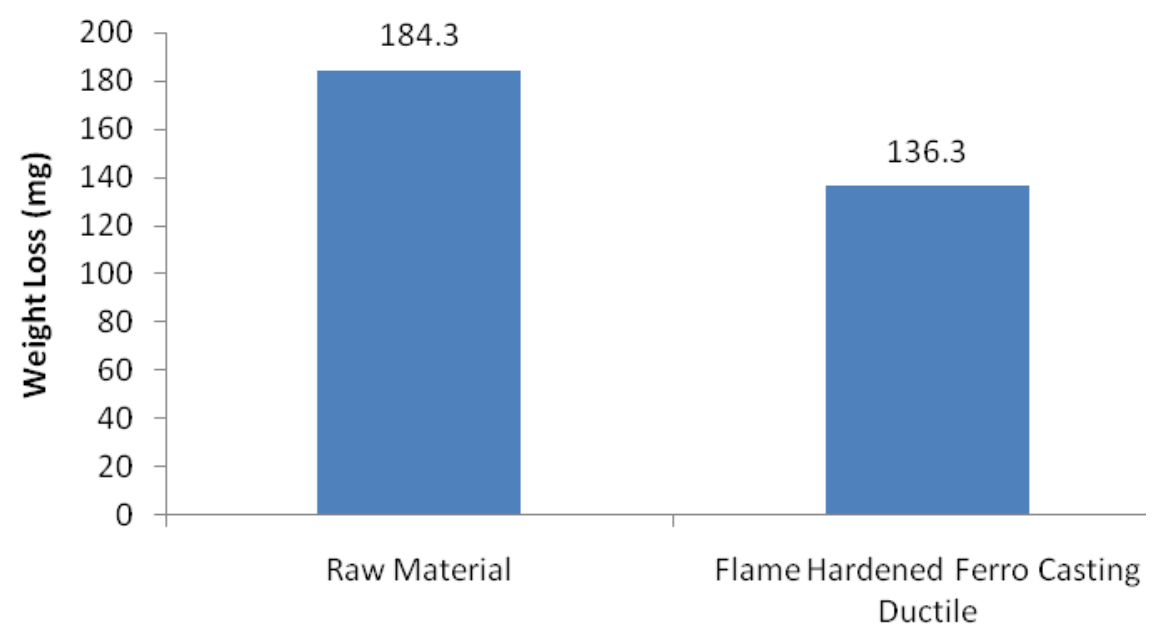

Material

Figure 5: The effect of flame hardening process on wear.

The data of the wear test results is shown in Figure 5. The wear test results are obtained, that the specimens without the flame hardening process had weight loss of $184.3 \mathrm{mg}$ which is higher than the specimens that are processed by the flame hardening process which had weight loss of $136.3 \mathrm{mg}$. So that the specimens without the flame hardening process have higher wear rates and have lower wear resistance. This is because at the edge of the flame hardened specimen has a higher hardness. The increase in hardness was caused by the presence of the bainite phase and the reduced amount of graphite. 
Agus Yulianto et al., International Journal of Emerging Trends in Engineering Research, 8(3), March 2020, 617- 622

\section{CONCLUSION}

From the test result, it can be concluded:

1. The flame hardening process which was carried out caused increasing hardness at the edge of the specimen. The highest hardness was $328.8 \mathrm{VHN}$

2. The flame hardening process carried out causes increased wear resistance of the specimen. The wear decreases from $184.3 \mathrm{mg}$ to $136.3 \mathrm{mg}$.

\section{ACKNOWLEDGEMENT}

The authors thanks the metallurgy laboratory of Universitas Muhammadiyah Surakarta, metallurgy laboratory of Brawijaya University and metal foundry engineering laboratory of Politeknik Manufaktur Ceper.

\section{REFERENCES}

1. F. Alabbasian, S. M. A. Boutorabi, and S. Kheirandish, Effect of inoculation and casting modulus on the microstructure and mechanical properties of ductile NI-resist cast iron, Materials Science and Engineering: A, vol. 651, pp. 467-473, 2016. https://doi.org/10.1016/j.msea.2015.09.024

2. T. N. F. Souza, R. A. P. S. Nogueira, F. J. S. Franco, M. T. P. Aguilar, and P. R. Cetlin. Mechanical and Microstructural Characterization of Nodular Cast Iron (NCI) with Niobium Additions, Materials Research, vol. 17, no. 5, pp. 1167-1172, 2014.

3. C. Soriano, J. Leunda, J. Lambarri, V. G. Navas, and C. Sanz. Effect of laser surface hardening on the microstructure, hardness and residual stresses of austempered ductile iron grades, Applied Surface Science, vol. 257, no. 16, pp. 7101-7106, 2011. https://doi.org/10.1016/j.apsusc.2011.03.059

4. R. O. Giacomelli, D. B. Salvaro, C. Binder, A. N. Klein, and J. D. B. de Mello. DLC deposited onto nitrided grey and nodular cast iron substrates: An unexpected tribological behavior, Tribology International, vol. 121, pp. 460-467, 2018.

5. M. Gelfi, A. Pola, L. Girelli, A. Zacco, M. Masotti, and G. M. La Vecchia. Effect of heat treatment on microstructure and erosion resistance of white cast irons for slurry pumping applications, Wear, vol. 428-429, pp. 438-448, 2019.

6. A. Sadeghi, A. Moloodi, M. Golestanipour, and M. M. Shahri. An investigation of abrasive wear and corrosion behavior of surface repair of gray cast iron by SMAW, Journal of Materials Research and Technology, vol. 6, no. 1, pp. 90-95, 2017.

7. J. P. Zou, K. Shimizu, and Q. Z. Cai. Effects of Cr Content and Annealing Temperature on Microstructure and Wear Characteristics of Cast Ausferrite Nodular Iron, Journal of Iron and Steel Research International, vol. 22, no. 11, pp. 1049-1054, 2015.
8. V. Oksanen, P. Andersson, K. Valtonen, K. Holmberg, \& V. T. Kuokkala. Characterization of the wear of nodular cast iron rollers in contact with wire ropes, Wear, vol. 308, pp. 199-205, 2013.

https://doi.org/10.1016/j.wear.2013.06.014

9. K. Jhaveri, G. M. Lewis, J. L. Sullivan, and G. A. Keoleian. Life cycle assessment of thin-wall ductile cast iron for automotive light weighting applications, Sustainable Materials and Technologies, vol. 15, pp. $1-8,2018$.

10. S. Schoenborn, H. Kaufmann, C. M. Sonsino, and R. Heim. Variable amplitude fatigue of high-strength cast iron alloys for automotive applications, International Journal of Fatigue, vol. 91, pp. 445-458, 2016

11. M. Pevec, G. Oder, I. Potrč, and M. Šraml. Elevated temperature low cycle fatigue of grey cast iron used for automotive brake discs, Engineering Failure Analysis, vol. 42, pp. 221-230, 2014.

12. M. Bazdar, H. R. Abbasi, A. H. Yaghtin, and J. Rassizadehghan. Effect of sulfur on graphite aspect ratio and tensile properties in compacted graphite irons, Journal of Materials Processing Technology, vol. 209, pp. 1701-1705, 2009.

13. P. Čanžar, Z. Tonković, and J. Kodvanj. Microstructure influence on fatigue behaviour of nodular cast iron, Materials Science and Engineering: A, vol. 556, pp. 88-99, 2012

https://doi.org/10.1016/j.msea.2012.06.062

14. K. A. Jafar and A. A Behnam. Influence of Mold Preheating and Silicon Content on Microstructure and Casting Properties of Ductile Iron in Permanent Mold, Journal of Iron and Steel Research International, vol. 18, no. 3, pp. 34-39, 2011

15. Sunaryo, M. Efendy, Sarjito, and N. S. Kamarrudin. Pyrolysis of Plastic Waste as an Alternative Fuels in Spark Ignition Engine, International Journal of Emerging Trends in Engineering Research, vol. 7, no. 11, pp. 454-459, 2019. https://doi.org/10.30534/ijeter/2019/097112019

16. A. Hazim, H. M. Abduljalil, and A. Hashim. Structural, Electronic, Optical Properties and Antibacterial Application of Novel (PMMA- $\mathrm{Al}_{2} \mathrm{O}_{3}-\mathrm{Ag}$ ) Nano composites for Dental Industries Applications, International Journal of Emerging Trends in Engineering Research, vol. 7, no. 8, pp. 104-122, 2019 https://doi.org/10.30534/ijeter/2019/04782019.

17. M. Iasechko, V. Larin, D. Maksiuta, O. Ochkurenko, I. Krasnoshapka, Y. Samsonov, H. Lyashenko, A Zinchenko, and R. Vozniak. Model Description of the Modified Solid State Plasma Material for Electromagnetic Radiation Protection, International Journal of Emerging Trends in Engineering Research, vol. 7, no. 10, pp. 376-382, 2019. https://doi.org/10.30534/ijeter/2019/027102019

18. O. O. Oluwole, O. E. Olorunniwo, O. O. Ogundare, P. O. Atanda, and O. O. Oridota. Effect of Magnesium and 
Agus Yulianto et al., International Journal of Emerging Trends in Engineering Research, 8(3), March 2020, 617- 622

Calcium as Spheroidizers on the Graphite Morphology in Ductile Cast Iron, Journal of Minerals \& Materials Characterization \& Engineering, vol. 6, no. 1, pp. 25-37, 2007.

19. C. A. Huang, C. K. Lin, C. W. A. Chiou, and F. Y Hsu. Microstructure study of the hardening mechanism of Cr-Ni alloy deposits after flame heating for a few seconds, Surface and Coatings Technology, vol. 206, no. 2-3, pp. 325-329, 2011.

20. İ. Hacısalihoğlu, F. Yıldız, and A. Çelik. Tribocorrosion behavior of plasma nitrided Hardox steels in NaCl solution, Tribology International, vol. 120, pp. 434-445, 2018.

21. A. S. Darmawan, W. A. Siswanto, and T. Sujitno. Comparison of Commercially Pure Titanium Surface Hardness Improvement by Plasma Nitrocarburizing and Ion Implantation, Advanced Materials Research, vol. 789, pp. 347-351, 2013.

22. M. K. Lee, G. H. Kim, K. H. Kim, and W. W. Kim. Control of surface hardnesses, hardening depths, and residual stresses of low carbon $12 \mathrm{Cr}$ steel by flame hardening, Surface and Coatings Technology, vol. 184, no. 2-3, pp 239-246, 2004.

23. M. K. Lee, G. H. Kim, K. H. Kim, and W. W. Kim. Effects of the surface temperature and cooling rate on the residual stresses in a flame hardening of $12 \mathrm{Cr}$ steel, Journal of Materials Processing Technology, vol. 176, no. 1-3, pp. 140-145, 2006. 